\title{
DNA Adsorption by Indium Tin Oxide (ITO) Nanoparticles
}

\author{
Biwu Liu and Juewen Liu* \\ Department of Chemistry, Waterloo Institute for Nanotechnology, \\ University of Waterloo, Waterloo, Ontario, Canada, N2L 3G1 \\ Email: liujw@uwaterloo.ca
}

This document is the Accepted Manuscript version of a Published Work that appeared in final form in Langmuir, copyright (C) American Chemical Society after peer review and technical editing by publisher. To access the final edited and published work see http://dx.doi.org/10.1021/la503917j 


\begin{abstract}
Indium tin oxide (ITO) is a highly important material since it is both conductive and transparent. As a result, ITO is widely used in the electronic industry and recently its application in biosensor development is also explored. We herein investigate its interaction with DNA by studying the adsorption of fluorescently labeled and single-stranded oligonucleotides onto ITO nanoparticles. The fluorescence of DNA is efficiently quenched after adsorption and the interaction between DNA and ITO NPs is dependent on the surface charge of ITO, which is controlled by $\mathrm{pH}$. Adsorption is greatly enhanced at low $\mathrm{pH}$. Adsorption is also influenced by the sequence and length of DNA. For its components, $\operatorname{In}_{2} \mathrm{O}_{3}$ adsorbs DNA more strongly while $\mathrm{SnO}_{2}$ repels DNA at neutral $\mathrm{pH}$. The DNA adsorption property is an averaging result from both components. DNA adsorption is confirmed to be mainly by the phosphate backbone via displacement experiments using free phosphate or DNA bases. Lastly, DNA induced DNA desorption by forming duplex DNA is demonstrated on ITO, while the same reaction is more difficult to achieve on other metal oxides including $\mathrm{CeO}_{2}, \mathrm{TiO}_{2}$ and $\mathrm{Fe}_{3} \mathrm{O}_{4}$.
\end{abstract}




\section{Introduction}

DNA-functionalized nanomaterials have attracted extensive research interests. These hybrid materials combine the molecular recognition and programmable property of DNA with the physical properties of inorganic nanoparticles, showing promising applications in many fields including biosensing, ${ }^{1-5}$ drug delivery, ${ }^{6}$ materials science,${ }^{7-8}$ and nanotechnology ${ }^{9-12}$ Over the past two decades, many nanomaterials, such as metallic nanoparticles, ${ }^{13}$ semiconductor quantum dots, ${ }^{14}$ and nanoscale carbon materials (e.g. carbon nanotubes and graphene oxide),${ }^{15}$ have been modified with DNA. Each type of material has its own interaction force for DNA adsorption.

A key step in constructing such materials is the attachment of DNA to the particle surface. Depending on the surface chemistry, several conjugation methods have been developed, including covalent bonding, metal coordination, and physisorption. ${ }^{16}$ While covalent attachment provides a strong linkage with DNA, physisorption is attractive due to its simplicity, cost-effectiveness and reversible binding. For examples, DNA is readily adsorbed onto the graphene oxide surface via $\pi-\pi$ stacking, and the complementary DNA (cDNA) induces DNA desorption by forming a duplex. ${ }^{15,17}$ For gold nanoparticles (AuNPs), while thiolated DNA is the main reagent for attachment, non-thiolated DNA has recently emerged as an alternative. ${ }^{18-19}$

Metal oxides encompass a large number of important materials. In the last few years, the adsorption of DNA onto several metal oxides has been investigated. ${ }^{20-25}$ For example, by 
forming a DNA layer, the catalytic property of $\mathrm{CeO}_{2}$ was altered. ${ }^{21}$ Fluorescently labeled DNA molecules were used to detect arsenate ions in water based on the competitive adsorption onto iron oxide nanoparticles. ${ }^{22}$

Indium-doped tin oxide (ITO) is a very important material because it is both transparent and conductive. ${ }^{26}$ ITO electrodes are used in electrical ${ }^{27}$ and photolectrochemical ${ }^{28}$ biosensors for DNA as well as other targets. For example, Gao et al developed a photoelectrochemical DNA sensor by conjugating an aldehyde-modified capture DNA onto a silanized ITO electrode. ${ }^{29}$ The cDNA hybridization was followed by tagging a photoactive intercalator and the increased photocurrent. In other applications, direct DNA-ITO interaction was utilized for the detection of cDNA, ${ }^{30}$ DNA methylation, ${ }^{31}$ and pathogen. ${ }^{32}$ At the same time, nanoscale ITO particles are particular interesting in making electrodes. ${ }^{33-34}$ Some DNA-ITO nanoparticle (NP) conjugates have been made into conductive networks for DNA detection. ${ }^{35}$ In spite of these analytical applications, little is known about the fundamental interactions between DNA and ITO. In this work, we study the adsorption of DNA oligomers on ITO NPs as a function of $\mathrm{pH}$, salt concentration, and DNA sequence. By changing the oxide composition and displacement experiments, we also proposed the adsorption mechanism. Finally, ITO was used to achieve DNA induced DNA desorption, which was found to be more difficult with other types of metal oxides. 


\section{Material and Methods}

\section{Chemicals.}

All of the DNA samples were purchased from Eurofins Scientific (Huntsville AL). Their sequences and modifications are shown in Table 1 . The indium oxide NPs $\left(\operatorname{In}_{2} \mathrm{O}_{3}, 20-70 \mathrm{~nm}\right.$, stock number US3250), tin dioxide NPs ( $\mathrm{SnO}_{2}, 18 \mathrm{~nm}$, stock number US3470) and indium tin oxide NPs $\left(\mathrm{In}_{2} \mathrm{O}_{3}: \mathrm{SnO}_{2}=90: 10,20-70 \mathrm{~nm}\right.$, stock number US3855) were purchased from US Research Nanomaterials, Inc. (Houston, TX). Other metal oxides were from Sigma-Aldrich. Sodium acetate, sodium citrate, sodium phosphate, sodium chloride, 4-(2-hydroxyethyl) piperazine-1-ethanesulfonic acid (HEPES), 2-(N-morpholino) ethanesulfonic acid (MES) and nuclesosides were from Mandel Scientific (Guelph, ON, Canada). Milli-Q water was used for all of the experiments.

Table 1. The sequences of DNA used in this work

\begin{tabular}{ll}
\hline DNA names & Sequences (from $\mathbf{5}^{\prime}$ to $\mathbf{3}^{\prime}$ ) and modifications \\
\hline Alexa-DNA1 & TCA CAG ATG CGT-Alexa Fluoro 488 \\
FAM-DNA2 & FAM-ACG CAT CTG TGA AGA GAA CCT GGG \\
sDNA & ACG CAT CTG TGA AGA GAA CCT GGG \\
cDNA & CCC AGG TTC TCT TCA CAG ATG CGT \\
FAM-A 5 & FAM-AAA AA \\
FAM-A 15 & FAM-AAA AAA AAA AAA AAA \\
FAM-T15 & FAM-TTT TTT TTT TTT TTT \\
FAM-C 15 & FAM-GGG GGG GGG GGG GGG \\
FAM-G 15 & FAM-CCC CCC CCC CCC CCC \\
FAM-A 30 & FAM-AAA AAA AAA AAA AAA AAA AAA AAA AAA AAA \\
\hline
\end{tabular}




\section{Dynamic light scattering (DLS)}

The $\zeta$-potential of oxide dispersions was measured by DLS using Malvern Nanosizer ZS90. To measure the $\zeta$-potential at different $\mathrm{pH}$, the oxides were dispersed in designed $\mathrm{pH}$ buffers (10 mM, acetate buffer for $\mathrm{pH} 4$ and 5, MES for $\mathrm{pH} 6$, and HEPES for $\mathrm{pH} 7$ and 8). The final concentration of ITO NPs is $50 \mu \mathrm{g} / \mathrm{mL}$ for most experiments unless otherwise specified.

\section{DNA adsorption and desorption kinetics}

To study the effect of $\mathrm{pH}$ on adsorption kinetics, Alexa-DNA1 (10 nM) was dissolved into buffers at different $\mathrm{pH}(10 \mathrm{mM})$. The initial fluorescence $\left(F_{0}\right)$ was monitored for $3 \mathrm{~min}$ (excitation at $485 \mathrm{~nm}$, emission at $535 \mathrm{~nm}$ ) using a microplate reader (Infinite F200Pro, Tecan). After a quick addition of ITO NP dispersion, the fluorescence was monitored for another $20 \mathrm{~min}$. The time-dependent studies of DNA adsorption at various $\mathrm{NaCl}$ concentrations or onto different oxides were performed in a similar way. To study desorption of DNA from ITO NP surface, the DNA-ITO conjugates were prepared as described above at designed conditions. To test the effect of $\mathrm{pH}$ on DNA desorption, for example, the DNA-ITO conjugates were prepared by incubating Alexa-DNA1 $(300 \mathrm{nM})$ with ITO NPs $(500 \mu \mathrm{g} / \mathrm{mL})$ at $\mathrm{pH} 4$ for $1 \mathrm{~h}$. After diluting the conjugated with Mill-Q water 10 times and monitoring the background fluorescence for $3 \mathrm{~min}$, the $\mathrm{pH}$ was adjusted by adding $20 \mathrm{mM} \mathrm{pH} 7$ or $\mathrm{pH} 8$ HEPES buffer. The fluorescence was monitored for another $30 \mathrm{~min}$. To test the effects of ionic strength on desorption at $\mathrm{pH} 4$, the conjugates were prepared in the same way and the ionic strength was adjusted by adding various volumes of $5 \mathrm{M} \mathrm{NaCl}$. To study displacement, the final concentrations of nucleosides and anions were $1 \mathrm{mM}$. 


\section{DNA loading capacity}

The DNA loading capacity was measured based on the fluorescence decrease upon adding ITO or other oxides under various designed conditions. To test the effect of $\mathrm{NaCl}$ on DNA loading capacity at $\mathrm{pH}$ 7.6, for example, FAM-DNA2 (30 nM) was incubated with ITO (50 $\mu \mathrm{g} / \mathrm{mL}$ ) at varying concentrations of $\mathrm{NaCl}$. After $2 \mathrm{~h}$ incubation, the fluorescence was measured to calculate adsorbed DNA.

\section{DNA induced desorption}

To study cDNA induced DNA desorption, FAM-DNA2 $(10 \mathrm{nM})$ was incubated with ITO NPs

$(60 \mu \mathrm{g} / \mathrm{mL})$ for $2 \mathrm{~h}$ and then dispersed in buffer solution (HEPES $10 \mathrm{mM}$, pH 7.6). After adding cDNA and $1 \mathrm{~h}$ reaction, the fluorescence was recorded. For the selectivity study, same amount of cDNA and the same DNA (10 nM) was added. To compare different oxides, the DNA-oxides conjugates were prepared in the same buffer condition. The concentration of probe DNA (FAM-DNA2) and cDNA were both $10 \mathrm{nM}$. The concentrations of oxides are as follows: $\left[\mathrm{TiO}_{2}\right]=10 \mu \mathrm{g} / \mathrm{mL},\left[\mathrm{Fe}_{3} \mathrm{O}_{4}\right]=12 \mu \mathrm{g} / \mathrm{mL},\left[\mathrm{CeO}_{2}\right]=1 \mu \mathrm{g} / \mathrm{mL}$, and $\left[\mathrm{In}_{2} \mathrm{O}_{3}\right]=50$ $\mu \mathrm{g} / \mathrm{mL}$ 


\section{Results and Discussion}

Effect of surface charge. To have a complete understanding, in addition to ITO, we also studied $\mathrm{In}_{2} \mathrm{O}_{3}$ and $\mathrm{SnO}_{2}$, which are the basic ingredient of ITO. Instead of studying bulk planar surfaces, we chose to use their NPs to achieve a large surface area and high adsorption capacity. In addition, NP interaction with DNA can be conveniently followed by optical spectroscopy in the solution phase. These three oxides are crystalline as indicated by XRD (Figure S1). From TEM (Figure S2), the diameter of ITO NPs is ca. $50 \mathrm{~nm}$. All these NPs appear aggregated, which is also reflected from their hydrodynamic sizes (e.g. $>200 \mathrm{~nm}$ ) by dynamic light scattering (DLS, Figure S3). Aggregation is attributed to the lack of strong capping ligands and weak surface charge (vide infra). We are interested in studying DNA interaction with the native oxide surface, and intentionally avoided adding strong ligands.

Since DNA is highly negatively charged, the surface charge of the oxides is likely to be important for determining the interaction force. We next measured the $\zeta$-potential of the NPs as a function of $\mathrm{pH}$ (Figure 1A). All the three NPs are positively charged at low $\mathrm{pH}$ and negatively charged at high $\mathrm{pH}$. The point of zero charge (PZC) is however different for each one. The ITO NPs are negatively charged when $\mathrm{pH}$ is higher than 7 and its PZC is between pH 6 and 7. Interestingly, the $\mathrm{PZC}$ of $\mathrm{SnO}_{2}$ is close to 4 and $\mathrm{In}_{2} \mathrm{O}_{3}$ is between 7 and 8 . This suggests that the surface charge of ITO might be controlled by either tuning $\mathrm{pH}$ or by changing the $\mathrm{Sn} / \mathrm{In}$ ratio. Most oxides are capped by hydroxide groups in water, and their surface charge normally comes from the (de)protonation of these $-\mathrm{OH}$ groups.

After understanding surface charge, we tested the effect of $\mathrm{pH}$ for DNA adsorption. We 
employed an Alexa Fluoro 488 (AF) labeled 12-mer DNA (Alexa-DNA1) and this fluorophore is insensitive to $\mathrm{pH}$ change. At $\mathrm{pH} 4$, all the three NPs quenched the fluorescence (Figure 1B). This indicates two important facts. First, DNA can be adsorbed by all these NPs at $\mathrm{pH}$ 4. Second, these NPs can quench adsorbed fluorophores, which provides a convenient method for subsequent studies. This is consistent with that all the NPs are positively charged at $\mathrm{pH}$ 4. At $\mathrm{pH} 7$, almost no quenching was observed for $\mathrm{SnO}_{2}$, and ITO showed moderate quenching. Full quenching was achieved only with $\operatorname{In}_{2} \mathrm{O}_{3}$. This trend also agrees with the surface charging of the NPs at $\mathrm{pH}$ 7. This simple experiment established that AF-labeled DNA is a useful probe for studying DNA adsorption.
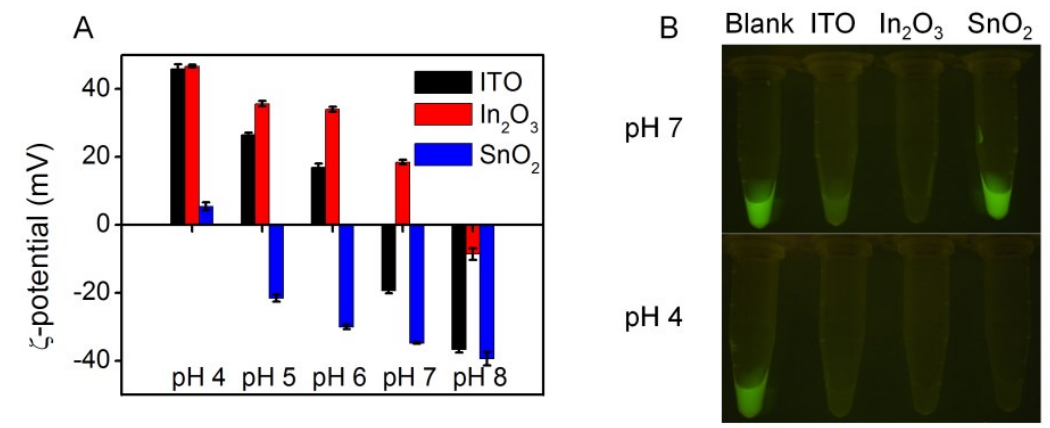

Figure 1. (A) The effect of $\mathrm{pH}$ on the $\zeta$-potential of $\mathrm{ITO}, \mathrm{In}_{2} \mathrm{O}_{3}$ and $\mathrm{SnO}_{2}$ NPs. (B) Photographs showing fluorescence quenching of Alexa-DNA1 (100 nM) by the three oxide NPs $(500 \mu \mathrm{g} / \mathrm{mL})$ at $\mathrm{pH} 7$ and $\mathrm{pH}$ 4. The blank groups are the free DNA without any oxides. The photographs were taken under a Safe Imager ${ }^{\text {TM }} 2.0$ Blue-Light Transilluminator by a digital camera.

For a quantitatively study, we measured the kinetics of DNA adsorption (Figure 2A). At $\mathrm{pH} 8$, almost no DNA was adsorbed onto ITO NPs as indicated by stable fluorescence signals. 
However, a dramatic fluorescence decrease was observed at $\mathrm{pH} 6$ attributable to the change of surface charge of ITO NPs from negative to positive. The rate of adsorption is quite fast, approaching equilibrium in $\sim 1 \mathrm{~min}$ at $\mathrm{pH} 6$, while slower adsorption occurred at $\mathrm{pH} 7$. The effect of $\mathrm{pH}$ was also studied by measuring the DNA loading capacity at various $\mathrm{pH}$ 's (Figure 2B). Using a higher concentration of DNA and after $2 \mathrm{~h}$ incubation, over $95 \%$ DNA adsorption was achieved at low $\mathrm{pH}$, while less than 5\% DNA was adsorbed at $\mathrm{pH} 8$.

Next we studied the reversibility of DNA adsorption. When the $\mathrm{pH}$ of the prepared DNA-ITO conjugates was adjusted back to neutral or basic, a fast fluorescence increase was observed (Figure 2C), suggesting DNA desorption. Combined with the $\zeta$-potential measurement in Figure 1A, we conclude that electrostatic interaction plays a critical role in DNA adsorption.
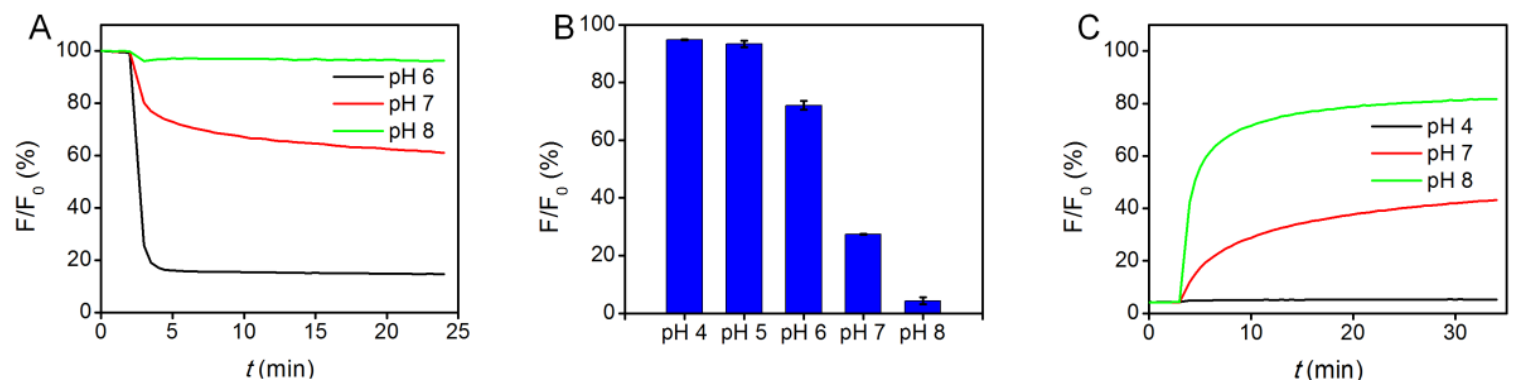

Figure 2. Effect of $\mathrm{pH}$ on the (A) adsorption kinetics, (B) loading capacity, and (C) desorption kinetics of Alexa-DNA1 by ITO. The buffer concentration is $10 \mathrm{mM}$ in the absence of additional salt.

Effect of ionic strength. Since most DNA assays are performed at neutral or physiological 
$\mathrm{pH}$, next we studied DNA adsorption at $\mathrm{pH}$ 7.6. At this $\mathrm{pH}$, both DNA and ITO NPs are negatively charged, and adding salt might be useful for screening charge repulsion. Figure 3A shows the adsorption kinetics as a function of $\mathrm{NaCl}$ concentration. In the absence of $\mathrm{NaCl}$, there is a fast initial fluorescence drop followed by a slow decrease. The addition of $\mathrm{NaCl}$ indeed increased the adsorption rate. However, salt concentration did not appear to very important, where similar adsorption was achieved with $30 \mathrm{mM}$ and $300 \mathrm{mM} \mathrm{NaCl}$. The effect of $\mathrm{NaCl}$ on DNA loading capacity is also similar (Figure 3C). With over $30 \mathrm{mM}$ salt, the capacity reached saturation. This study suggests that the electrostatic repulsion is quite weak between DNA and ITO at pH 7.6 and it can be effectively screened with just $30 \mathrm{mM} \mathrm{NaCl}$.

From the DNA loading capacity data, we reason that the electrostatic repulsion among DNA is also weak on ITO. For example, adsorption of thiolated DNA by AuNPs is strongly influenced by $\mathrm{NaCl}$ concentration and the highest adsorption capacity was achieved at 700 $\mathrm{mM} \mathrm{NaCl}{ }^{36}$ Such high salt is mainly used to screen the repulsion among the dense DNA layer that are in an upright conformation. For ITO, the DNA capacity at neutral pH is much lower (vide infra) and salt only needs to screen the DNA/ITO repulsion.

Next, we compared the adsorption kinetics of FAM-labeled DNA2 by the three NPs (Figure 3B). As expected, $\mathrm{In}_{2} \mathrm{O}_{3}$ is the most effective in DNA adsorption, while $\mathrm{SnO}_{2}$ is the slowest, leaving ITO in between. This again agrees with the surface charging property. $\mathrm{SnO}_{2}$ is highly negatively charged at $\mathrm{pH} 7.6$ and the added $\mathrm{NaCl}$ was insufficient to screen the repulsion.

To further understand the mechanism of adsorption, the adsorption isotherm by ITO was 
measured (Figure 3D). It exhibits a typical Langmuir type of adsorption behavior, indicating monolayer and reversible adsorption. The highest DNA loading coverage is ca. $12 \mathrm{nM}$ for a 24-mer DNA (FAM-DNA2) onto $50 \mu \mathrm{g} / \mathrm{mL}$ ITO NPs. Assume the NPs are $50 \mathrm{~nm}$ in diameter and $50 \mu \mathrm{g} / \mathrm{mL}$ of ITO NPs is ca. $0.178 \mathrm{nM}$. Therefore each ITO NP adsorbs 68 molecules of

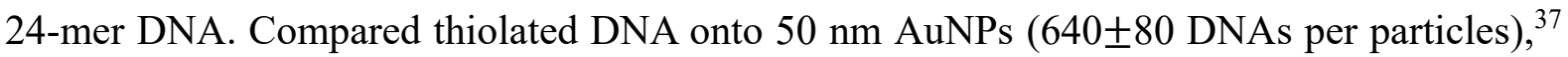
this coverage is much lower. This suggests that the DNA wraps around ITO instead of adopting an upright conformation as in the case of AuNPs.
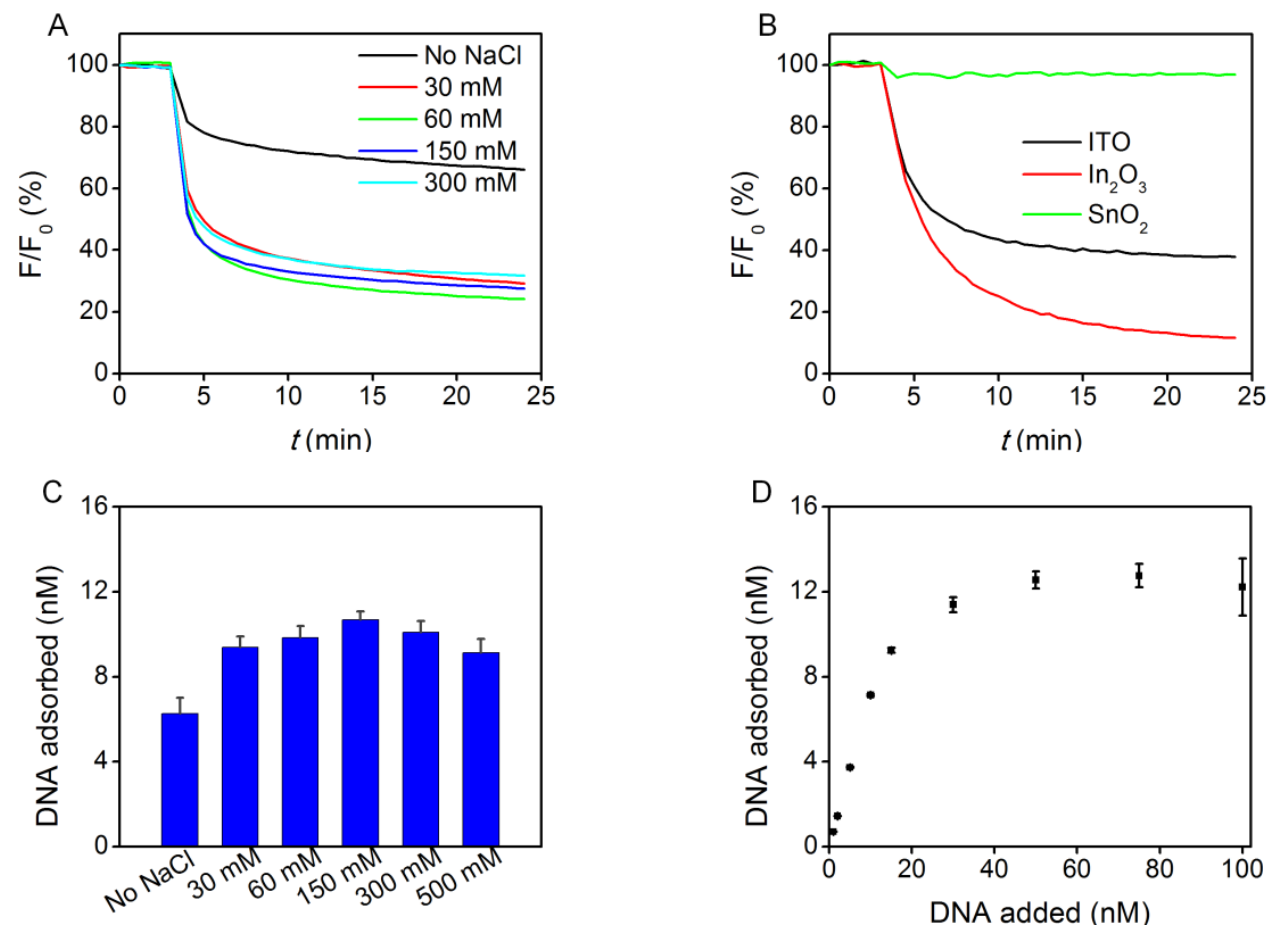

Figure 3. Adsorption kinetics (A) and loading capacity (C) of FAM-DNA2 on ITO NPs as a function of $\mathrm{NaCl}$ concentration (10 mM HEPES, $\mathrm{pH}$ 7.6). (B) The DNA adsorption kinetics onto various oxides. (D) DNA adsorption isotherm by ITO NPs with $150 \mathrm{mM} \mathrm{NaCl}$ at $\mathrm{pH}$ 7.6. $\mathrm{NP}$ concentration $=50 \mu \mathrm{g} / \mathrm{mL}$. 
Effect of DNA length and sequence. One advantage of DNA-based assays is that the length and sequence of DNA can be readily controlled, which may provide further mechanistic insights. The loading of FAM labeled homo 15-mer DNA at pH $7.6(\mathrm{NaCl} 150 \mathrm{mM})$ and at pH 4 was performed (Figure 4). The loading capacities of all DNA at pH 4.0 are 50-100 folds of those at $\mathrm{pH} 7.6$, highlighting the importance of surface charge of the oxides. Since poly-A and poly-C DNA can be partially protonated at $\mathrm{pH} 4$, they showed higher capacity than the poly-G and poly-T DNA.

Next, we studied the effect of DNA length (Figure 4B). At pH 4, the $\mathrm{A}_{15}$ DNA adsorbed the most. Although its loading is only $\sim 20 \%$ more than that for $\mathrm{A}_{5}$, its number of adenine nucleotide is $\sim 300 \%$ more. We reason that the 5 -mer DNA is too short and it has very weak affinity. On the other hand, the 30-mer DNA is too long and it occupies more footprints on the particle surface. The capacity of the 30 -mer DNA is roughly $50 \%$ of the 15 -mer and therefore, they adsorb a similar number of nucleotides. At $\mathrm{pH} 7.6$, all the DNAs were adsorbed with a very low capacity, and this is again attributed to the strong charge repulsion with the ITO surface.
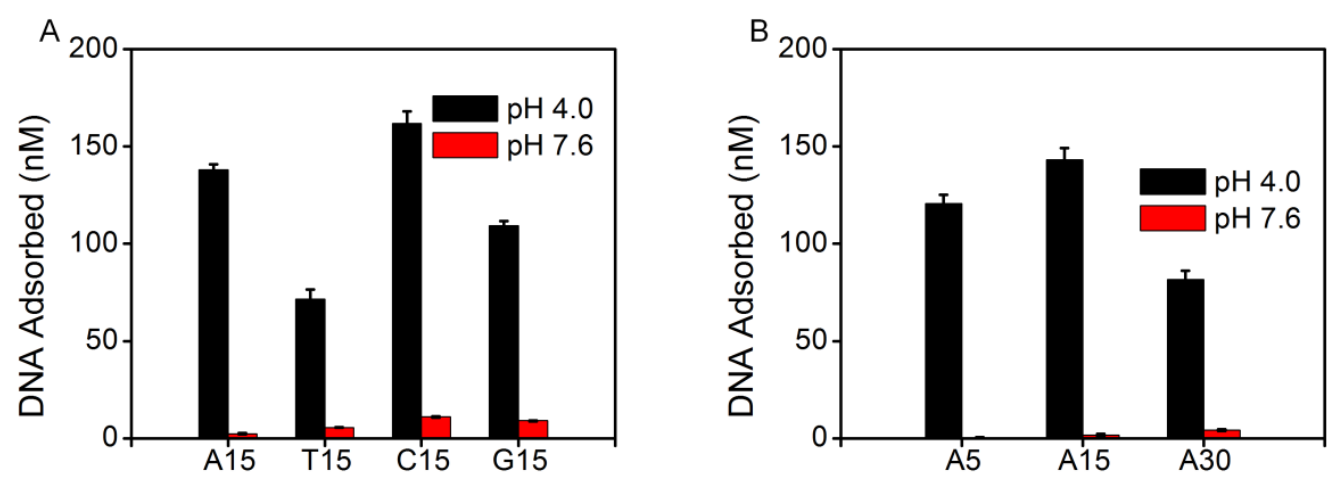

Figure 4. The effect of DNA sequence (A) and length (B) on loading capacity onto ITO NPs 
at $\mathrm{pH} 4.0$ and 7.6. The initial concentration of DNA added at $\mathrm{pH} 7.6$ and 4.0 are $30 \mathrm{nM}$ and $200 \mathrm{nM}$, respectively.

Adsorption mechanism. A DNA has two main components that could be responsible for adsorption: phosphate and the nucleobases. To understand the adsorption mechanism, a series of displacement experiments were carried out. The DNA-ITO conjugates were exposed to nucleosides and several anions. No significant DNA desorption was observed in the presence of the nucleosides at $\mathrm{pH} 7.6$, suggesting the lack of strong interaction between the bases and ITO (Figure 5A). We also tested the effect of various common anions (Figure 5B). Citrate and phosphate displaced adsorbed DNA quickly while the other anions had no effect. Therefore, it is likely that the phosphate on DNA backbone is responsible for DNA adsorption. After adding phosphate, the $\zeta$-potential of ITO NPs is also decreased (although still positive, Figure 5C), suggesting that phosphate partially caps the particle surface. Taken together, the phosphate backbone of DNA electrostatically adsorb onto ITO.
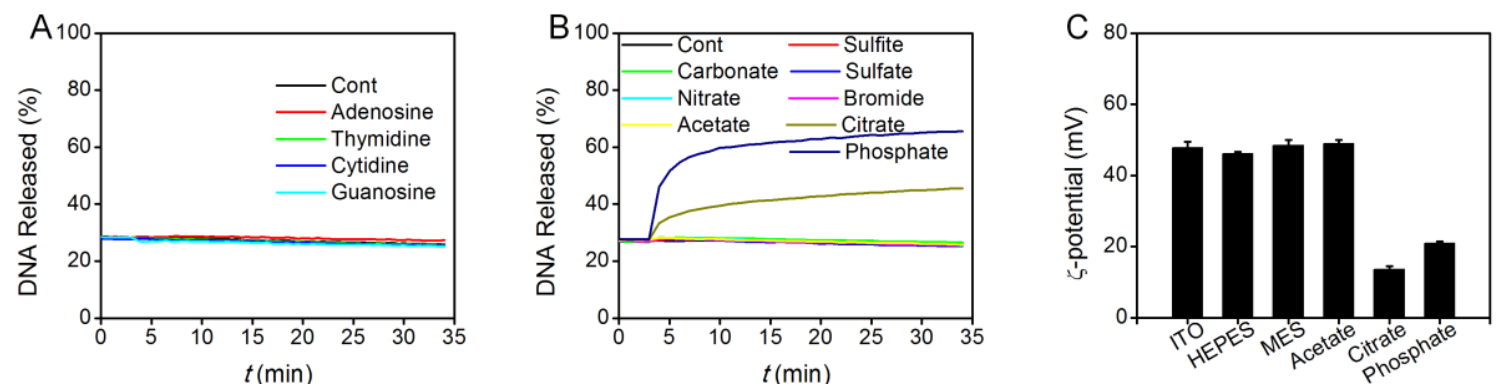

Figure 5. Displacement assays of DNA-ITO conjugates by (A) $1 \mathrm{mM}$ nucleosides and (B) 1 $\mathrm{mM}$ various anions. Only citrate and phosphate induced desorption. (C) $\zeta$-potential of ITO NPs at $\mathrm{pH} 4$ in the presence of various buffer anions $(100 \mu \mathrm{M})$. 
DNA induced desorption. After understanding DNA adsorption, we next studied cDNA induced desorption. The FAM-labeled probe DNA was first adsorbed onto ITO. Addition of cDNA induced a concentration-dependent fluorescence recovery (Figure 6A). As low as 0.7 nM cDNA can be detected based on signal greater than 3 times of background variation (inset). This performance is comparable to that reported with GO for a similar detection scheme ${ }^{15,38}$ It is interesting to note that at high cDNA concentration (e.g. $60 \mathrm{nM}$ ), the released FAM-DNA was only $66 \%$ of the adsorbed. The remaining probe were still adsorbed. This suggests that the surface of ITO might be heterogeneous and the places with more indium component might adsorb DNA more stably and cannot be released by the cDNA.

To test the specificity of this cDNA induced probe release, we also added a DNA with the same sequence as the probe DNA but non-labeled (named sDNA, Figure 6B). In this case, the released probe DNA was negligible, suggesting that formation of duplex is a driving force for DNA desorption. Since duplex DNA still maintains negatively charged property, it suggests that rigid duplex binding to ITO surface is less favorable compared to the flexible single-stranded DNA.

To compare ITO with other metal oxides, we adsorbed FAM-labeled DNA onto $\mathrm{TiO}_{2}$, $\mathrm{Fe}_{3} \mathrm{O}_{4}, \mathrm{CeO}_{2}$, and $\mathrm{In}_{2} \mathrm{O}_{3} . \mathrm{SnO}_{2}$ was not included since it does not adsorb DNA at pH 7.6. Then cDNA was added and only ITO resulted in a large fraction of DNA release (Figure 6C). Therefore, ITO is a unique metal oxide for DNA-induced DNA desorption (Figure 6D). This is attributed to the weak electrostatic interaction between DNA and ITO NPs. It is interesting to note that $\mathrm{In}_{2} \mathrm{O}_{3}$ exhibits a low response in the presence of cDNA, which might be related to 
its positive surface charge and can further adsorption the cDNA. It is like that $\mathrm{SnO}_{2}$ has a modulation effect to weaken adsorption capability. Our ITO NPs contain $10 \% \mathrm{SnO}_{2}$ and $90 \%$ $\mathrm{In}_{2} \mathrm{O}_{3}$, meaning that a small doping can significantly adjust the adsorption affinity.
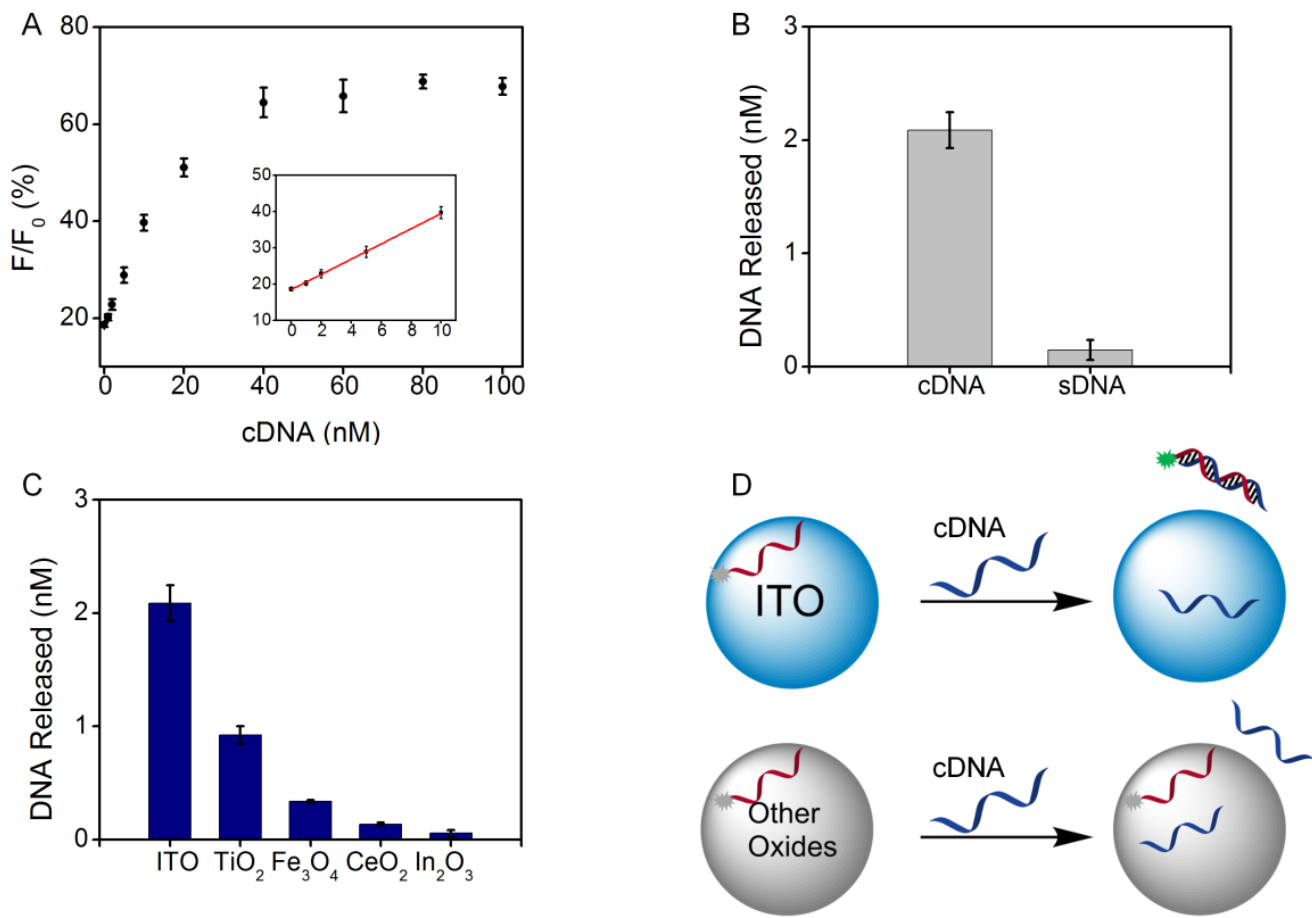

Figure 6. Sensing performance of FAM-DNA2 functionalized ITO. (A) Fluorescence response as a function of cDNA concentration after $1 \mathrm{~h}$ reaction. (B) Selectivity test in the presence of $10 \mathrm{nM}$ of cDNA and sDNA. (C) Comparison of several DNA-oxide conjugates in cDNA detection. The probe DNA and cDNA concentration are $10 \mathrm{nM}$ in all the samples. (D) A scheme of DNA desorption in the presence of cDNA from ITO. For other oxides, the cDNA induced DNA desorption is less efficient and likely the added cDNA is also adsorbed due to their stronger affinity for DNA. 


\section{Conclusions}

In summary, a systematic study was carried out to understand DNA adsorption by ITO. We show that fluorescently labeled single-strand of DNA can be adsorbed by ITO NPs, inducing fluorescence quenching. The surface charge of ITO is important in maximizing the DNA loading. From displacement experiments, DNA adsorption is mainly through the phosphate backbone via electrostatic interaction with the ITO surface. The ITO-DNA conjugate can be used to detect cDNA down to $0.7 \mathrm{nM}$. Interestingly, ITO shows an averaged behavior of $\mathrm{SnO}_{2}$ and $\operatorname{In}_{2} \mathrm{O}_{3}$. Doping the tin component has weakened DNA binding affinity, making it possible to directly detect cDNA. For comparison, most other oxides adsorb DNA too tightly and the adsorbed DNA cannot be easily desorbed in the presence of cDNA. This study provided fundamental insights into DNA interaction with ITO, which is an important transparent electrode material useful for biosensor development.

\section{Acknowledgment}

Funding for this work is from the University of Waterloo, the Canadian Foundation for Innovation, and the Natural Sciences and Engineering Research Council (NSERC) of Canada, and the Early Researcher Award from the Ontario Ministry of Research and Innovation.

Supporting Information available. TEM, XRD, DLS of metal oxides. This material is available free of charge via the Internet at http://pubs.acs.org. 


\section{References}

(1) Rosi, N. L.; Mirkin, C. A. Nanostructures in Biodiagnostics. Chem. Rev. 2005, 105, $1547-1562$.

(2) Wang, H.; Yang, R. H.; Yang, L.; Tan, W. H. Nucleic Acid Conjugated Nanomaterials for Enhanced Molecular Recognition. ACS Nano 2009, 3, 2451-2460.

(3) Liu, J.; Cao, Z.; Lu, Y. Functional Nucleic Acid Sensors. Chem. Rev. 2009, 109, 1948-1998.

(4) Song, S. P.; Qin, Y.; He, Y.; Huang, Q.; Fan, C. H.; Chen, H. Y. Functional Nanoprobes for Ultrasensitive Detection of Biomolecules. Chem. Soc. Rev. 2010, 39, 4234-4243.

(5) Zhao, W.; Brook, M. A.; Li, Y. Design of Gold Nanoparticle-Based Colorimetric Biosensing Assays. ChemBioChem 2008, 9, 2363-2371.

(6) Giljohann, D. A.; Seferos, D. S.; Daniel, W. L.; Massich, M. D.; Patel, P. C.; Mirkin, C. A. Gold Nanoparticles for Biology and Medicine. Angew. Chem. Int. Ed. 2010, 49, 3280-3294.

(7) Park, S. Y.; Lytton-Jean, A. K. R.; Lee, B.; Weigand, S.; Schatz, G. C.; Mirkin, C. A. DNA-programmable Nanoparticle Crystallization. Nature 2008, 451, 553-556.

(8) Nykypanchuk, D.; Maye, M. M.; van der Lelie, D.; Gang, O. DNA-guided Crystallization of Colloidal Nanoparticles. Nature 2008, 451, 549-552.

(9) Katz, E.; Willner, I. Integrated Nanoparticle-Biomolecule Hybrid Systems: Synthesis, Properties, and Applications. Angew. Chem. Int. Ed. 2004, 43, 6042-6108.

(10) Cheng, W. L.; Campolongo, M. J.; Cha, J. J.; Tan, S. J.; Umbach, C. C.; Muller, D. A.; Luo, D. Free-standing Nanoparticle Superlattice Sheets Controlled by DNA. Nat. Mater. 2009, 
$8,519-525$.

(11) Pinheiro, A. V.; Han, D.; Shih, W. M.; Yan, H. Challenges and Opportunities for Structural DNA Nanotechnology. Nat. Nanotechnol. 2011, 6, 763-772.

(12) Lu, Y.; Liu, J. Smart Nanomaterials Inspired by Biology: Dynamic Assembly of Error-Free Nanomaterials in Response to Multiple Chemical and Biological Stimuli. Acc. Chem. Res. 2007, 40, 315-323.

(13) Mirkin, C. A.; Letsinger, R. L.; Mucic, R. C.; Storhoff, J. J. A DNA-based Method for Rationally Assembling Nanoparticles into Macroscopic Materials. Nature 1996, 382, 607-609.

(14) Mitchell, G. P.; Mirkin, C. A.; Letsinger, R. L. Programmed Assembly of DNA Functionalized Quantum Dots. J. Am. Chem. Soc. 1999, 121, 8122-8123.

(15) Lu, C.-H.; Yang, H.-H.; Zhu, C.-L.; Chen, X.; Chen, G.-N. A Graphene Platform for Sensing Biomolecules. Angew. Chem. Int. Ed. 2009, 48, 4785-4787.

(16) Sapsford, K. E.; Algar, W. R.; Berti, L.; Gemmill, K. B.; Casey, B. J.; Oh, E.; Stewart, M. H.; Medintz, I. L. Functionalizing Nanoparticles with Biological Molecules: Developing Chemistries that Facilitate Nanotechnology. Chem. Rev. 2013, 113, 1904-2074.

(17) Liu, B.; Sun, Z.; Zhang, X.; Liu, J. Mechanisms of DNA Sensing on Graphene Oxide. Anal. Chem. 2013, 85, 7987-7993.

(18) Pei, H.; Li, F.; Wan, Y.; Wei, M.; Liu, H.; Su, Y.; Chen, N.; Huang, Q.; Fan, C. Designed Diblock Oligonucleotide for the Synthesis of Spatially Isolated and Highly Hybridizable Functionalization of DNA-Gold Nanoparticle Nanoconjugates. J. Am. Chem. Soc. 2012, 134, 
11876-11879.

(19) Zhang, X.; Liu, B.; Dave, N.; Servos, M. R.; Liu, J. Instantaneous Attachment of an

Ultrahigh Density of Nonthiolated DNA to Gold Nanoparticles and Its Applications. Langmuir 2012, 28, 17053-17060.

(20) Zhang, X.; Wang, F.; Liu, B.; Kelly, E. Y.; Servos, M. R.; Liu, J. Adsorption of DNA Oligonucleotides by Titanium Dioxide Nanoparticles. Langmuir 2014, 30, 839-845.

(21) Pautler, R.; Kelly, E. Y.; Huang, P.-J. J.; Cao, J.; Liu, B.; Liu, J. Attaching DNA to Nanoceria: Regulating Oxidase Activity and Fluorescence Quenching. ACS Appl. Mater. Interfaces 2013, 5, 6820-6825.

(22) Liu, B.; Liu, J. DNA Adsorption by Magnetic Iron Oxide Nanoparticles and its Application for Arsenate Detection. Chem. Commun. 2014, 50, 8568-8570.

(23) Zuo, S.-H.; Zhang, L.-F.; Yuan, H.-H.; Lan, M.-B.; Lawrance, G. A.; Wei, G. Electrochemical Detection of DNA Hybridization by Using a Zirconia Modified Renewable Carbon Paste Electrode. Bioelectrochemistry 2009, 74, 223-226.

(24) Fahrenkopf, N. M.; Rice, P. Z.; Bergkvist, M.; Deskins, N. A.; Cady, N. C. Immobilization Mechanisms of Deoxyribonucleic Acid (DNA) to Hafnium Dioxide (HfO2) Surfaces for Biosensing Applications. ACS Appl. Mater. Interfaces 2012, 4, 5360-5368.

(25) He, D.; He, X.; Wang, K.; Yang, X.; Yang, X.; Li, X.; Zou, Z. Nanometer-sized Manganese Oxide-quenched Fluorescent Oligonucleotides: an Effective Sensing Platform for Probing Biomolecular Interactions. Chem. Commun. 2014, 50, 11049-11052.

(26) Liu, H.; Avrutin, V.; Izyumskaya, N.; Özgür, Ü.; Morkoç, H. Transparent Conducting 
Oxides for Electrode Applications in Light Emitting and Absorbing Devices. Superlattices Microstruct. 2010, 48, 458-484.

(27) Paleček, E.; Bartošík, M. Electrochemistry of Nucleic Acids. Chem. Rev. 2012, 112, $3427-3481$

(28) Zhao, W.-W.; Xu, J.-J.; Chen, H.-Y. Photoelectrochemical DNA Biosensors. Chem. Rev. 2014, $114,7421-7441$.

(29) Gao, Z.; Tansil, N. C. An Ultrasensitive Photoelectrochemical Nucleic Acid Biosensor. Nucleic Acids Res. 2005, 33, e123.

(30) Armistead, P. M.; Thorp, H. H. Modification of Indium Tin Oxide Electrodes with Nucleic Acids: Detection of Attomole Quantities of Immobilized DNA by Electrocatalysis. Anal. Chem. 2000, 72, 3764-3770.

(31) Wei, X.; Ma, X.; Sun, J.-j.; Lin, Z.; Guo, L.; Qiu, B.; Chen, G. DNA Methylation Detection and Inhibitor Screening Based on the Discrimination of the Aggregation of Long and Short DNA on a Negatively Charged Indium Tin Oxide Microelectrode. Anal. Chem. 2014, $86,3563-3567$.

(32) Patel, M. K.; Singh, J.; Singh, M. K.; Agrawal, V. V.; Ansari, S. G.; Malhotra, B. D. Tin Oxide Quantum Dot Based DNA Sensor for Pathogen Detection. J. Nanosci. Nanotechnol. 2013, 13, 1671-1678.

(33) Lee, J.; Lee, S.; Li, G.; Petruska, M. A.; Paine, D. C.; Sun, S. A Facile Solution-Phase Approach to Transparent and Conducting ITO Nanocrystal Assemblies. J. Am. Chem. Soc. 2012, 134, 13410-13414. 
(34) Yun, J.; Park, Y. H.; Bae, T.-S.; Lee, S.; Lee, G.-H. Fabrication of a Completely Transparent and Highly Flexible ITO Nanoparticle Electrode at Room Temperature. ACS Appl. Mater. Interfaces 2012, 5, 164-172.

(35) Fan, Y.; Chen, X.; Kong, J.; Tung, C.-h.; Gao, Z. Direct Detection of Nucleic Acids by Tagging Phosphates on Their Backbones with Conductive Nanoparticles. Angew. Chem. Int. Ed. 2007, 46, 2051-2054.

(36) Hurst, S. J.; Lytton-Jean, A. K. R.; Mirkin, C. A. Maximizing DNA Loading on a Range of Gold Nanoparticle Sizes. Anal. Chem. 2006, 78, 8313-8318.

(37) Hill, H. D.; Millstone, J. E.; Banholzer, M. J.; Mirkin, C. A. The Role Radius of Curvature Plays in Thiolated Oligonucleotide Loading on Gold Nanoparticles. ACS Nano 2009, 3, 418-424.

(38) He, S.; Song, B.; Li, D.; Zhu, C.; Qi, W.; Wen, Y.; Wang, L.; Song, S.; Fang, H.; Fan, C. A Graphene Nanoprobe for Rapid, Sensitive, and Multicolor Fluorescent DNA Analysis. Adv. Funct. Mater. 2010, 20, 453-459. 
For TOC graphics only

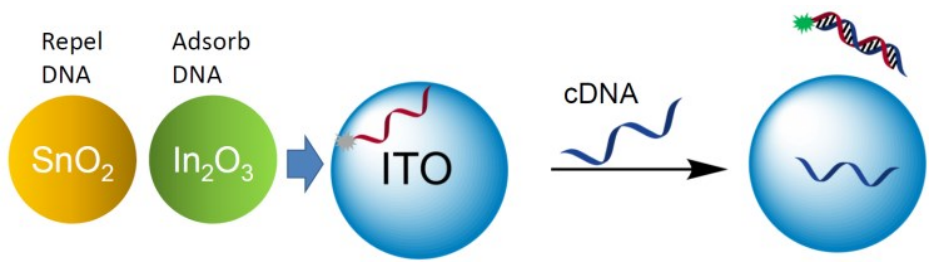

